\title{
NIH, under fire, freezes grant for conference on genetics and crime
}

Washington. Funding has been frozen for a forthcoming conference on the links between genetic disposition and crime after minority groups complained to its sponsor, the US National Institutes of Health (NIH), that the conference might be a veiled attack on African-Americans.

The critics said that the conference called "Genetic Factors in Crime: Findings, Uses and Implications" — was the latest manifestation of a federal "violence initiative" intended to find and treat biological causes of crime and violence. Because African-Americans make up 46 per cent of the US prison population, critics say that research correlating genetic traits to crime is likely to impugn African-Americans in particular.

Last week, the NIH director, Bernadine Healy, decided to delay a grant worth more than $\$ 100,000$ awarded to the University of Maryland Institute for Philosophy and Public Policy, sponsor of the conference. Healy learned of the controversy earlier this month from staff in the minority affairs and equal employment offices at $\mathrm{NIH}$, which received dozens of calls after panellists on two talk shows on the cable network Black Entertainment Television attacked the conference as racist.
An NIH spokeswoman says that the agency hopes to release the funds once the conference agenda is revised to address these concerns. The conference is scheduled for 9-11 October in College Park, Maryland.

The conference was peer-reviewed and approved last year by the ethical, legal and social implications branch of NIH's National Center for Human Genome Research. David Wasserman, organizer of the conference, calls the decision to freeze funding "an abdication of the integrity of the review process" stemming from a "misinterpretation of the purpose of the conference".

Wasserman concedes that the brochure advertising the conference may have oversimplified some of the issues to be discussed. It states that " $\mathrm{g}] \mathrm{enetic}$ research holds out the prospect of identifying individuals who may be predisposed to certain kinds of criminal conduct, of isolating environmental features which trigger those predispositions, and of treating some predispositions with drugs and unintrusive therapies".

However, Wasserman points out that genome administrators had no objections to the brochure when they read it, and he says that the NIH's decision to freeze the grant after receiving objections from minority groups is a form of "coercion".

\section{Society asks Brazil's president to resign}

São Paulo. Brazilian science, in the midst of a terrible funding crisis, has also become embroiled in a political fight with the country's president, Fernando Collor de Mellor.

The federal secretary for Science and Technology, Héllo Jaguaribe, traded verbal punches earlier this month with the president of the Brazilian Society for the Progress of IMAGE Science (SBPC), UNAVAILABLE after Candotti FOR called on Collor COPYRIGHT to resign to avoid REASONS possible impeachment. Brazil's Congress is investigating the

\section{Candotti in fight.} activities of Paulo César Farias, a businessman who handled the financing of Collor's presidential campaign in 1989 and who is now accused of using his position for personal gain. "He is turning it into the Brazilian Society for the Politicization of Science", says Jaguaribe about Candotti.
Joining the secretary in his attack on Candotti is José Goldemberg, a former science secretary and current Minister of Education, who is one of Collor's closest political advisers. Ironically, Goldemberg played an active role in national politics as SBPC president.

Goldemberg asked the society's main council to disown Candotti's statement, but instead the council backed its president. In retaliation, Jaguaribe threatened to withdraw funding for the society's various programmes, including its annual meeting, held two weeks ago in São Paulo. Jaguaribe retreated after he realized that it would repudiate the judgement of his secretariat.

The dispute takes place as funding from the government's leading source of basic academic research has shrunk by more than 40 per cent from 1990 to 1991, with an even sharper decline expected this year. The secretariat's main funding agency, the National Council for Scientific and Technological Development, has frozen new requests for grants and scholarships because it has been unable to distribute most of its funds for the current year.
One of the most vocal critics of the conference - and any research on the biological roots of crime - is Peter Breggin, director of the Center for the Study of Psychiatry in Bethesda, Maryland. In the current edition of the centre's newsletter, Breggin links the conference to controversial remarks made earlier this year by Frederick Goodwin, then director of the Alcohol, Drug Abuse, and Mental Health Administration (ADAMHA). Speaking to a federal advisory committee, Goodwin pointed to similarities between the behaviour of inner-city minority youth and monkeys subjected to environmental stress (see Nature 356, 6; 1992).

Goodwin's remarks drew strong criticism from the Congressional Black Caucus and other legislators, and within a few weeks his political bosses announced that Goodwin was stepping down to become director of the National Institute for Mental Health, one of three institutes within ADAMHA. At ADAMHA, Goodwin laid the groundwork for a federal "violence initiative" to investigate the biological roots of crime.

Research investigating the links between genetics and crime is a "fake subject", Breggin says, with no data that show a correlation between genetic factors and crime. "A conference [held] in the absence of such studies is racist", he adds.

Upon hearing the complaints, Healy decided to invite to NIH three of the scientists who reviewed the proposal for the conference to discuss their recommendations. Although one of the reviewers could not remember the proposal, another confessed to having second thoughts about the conference. In the absence of a "ringing endorsement" from the reviewers, says Joanna Schneider, an NIH spokeswoman, "we didn't have the feeling that we could defend [the conference]" against public criticism.

Rather than cancelling the grant, NIH asked Wasserman to form a multiracial advisory panel to examine the questions being raised. Although the panel has yet to meet, Wasserman expects that it will recommend that the scope of the conference be broadened to cover race relations, the social responsibilities of scientists and the need to consider the role of poverty and other environmental factors in understanding crime.

Although Wasserman says that the conference may be given a new title, the original concept will not change. "We don't want people to think that we ever assumed the existence of genetic factors", he says. "But we also have no intention of renaming the conference 'The Myth of Genetic Factors in Crime"”.

Christopher Anderson 